\title{
MANAGEMENT OF OPEN DUMPS IN ASIA CHALLENGES AND OPPORTUNITIES
}

\author{
Kurian Joseph \\ R. Nagendran \\ Anna University, India
}

\begin{abstract}
The open dump approach, a primitive version of municipal solid waste disposal remains the predominant option in most of the Asian countries. Problems of shortage of cover, lack of leachate collection and treatment, inadequate compaction of wastes, poor site design and ragpickers working and setting the refuse on fire to recover valuable inorganic items are common at such dumps. It is essential that an appropriate status quo analysis is carried out and an achievable, acceptable and affordable strategy and action plan are developed for implementation in a phased manner. This paper presents the steps that may be initiated to steadily move from open dumps towards controlled dumps and later to sustainable landfills based on the lessons learned from the on going project on "Sustainable Solid Waste Landfill Management in Asia" under the Asian Regional Research Programme on Environmental Technology funded by Swedish International Development Cooperation Agency and Coordinated by Asian Institute of Technology, Thailand.

The first step in upgrading open dumps to sanitary landfills involves reducing nuisances such as odors, dust, vermin, and birds. The principle of landfill mining may be used as the driver to convert this challenging task into an opportunity. The possible outcome would include recovery of space for future landfills, soil fraction for growing non edible crops as well as landfill cover material and the plastics for making refuse derived fuel. A natural remediation technique such as phytoremediation using higher vascular plants, though slow, is also worth considering.
\end{abstract}

\section{KEYWORDS}

Dumpsites, Landfill mining, Waste management, Rehabilitation.

\section{INTRODUCTION}

Open dumps, the most common mode of waste disposal in Asian cities, are sites on which solid wastes are disposed of in a manner that does not protect the environment and public health [1]. Such dumpsites pose several environmental and public health problems [2], such as:

- Open burning of garbage emanating smoke and causing air pollution

- Odour and fly nuisance

- Scavenging by the ragpickers

- Water logging and leaching during monsoon causing water pollution

- Dust nuisance due to vehicular movement

- Blowing of light materials like plastics, paper etc., due to winds 
- Trespassing and open defecation by the public

All the Asian cities have a common challenge of managing the old dumpsites in a scientific manner. Most of these cities, also, face a common problem of finding a space for waste processing and disposal facilities. Considering the difficulty in acquiring lands for the new waste disposal sites and obtaining consent from the neighbouring communities for their operation, the municipalities are increasingly opting for reclamation/use of the existing disposal sites by optimal management of the waste already stored at the site and housing waste processing and scientific landfill within them for managing the incoming municipal solid waste (MSW).

At present, the resources, funds and technical competence for upgrading/replacing the dumpsites and operating and maintaining them, are rather limited. Under such circumstances, the improvement of open dumping practices may be achieved by a step-by-step approach, maximizing the opportunities and benefits. Dumpsite rehabilitation would not only moderate the environmental impact of the improper disposal practice but also offer one or a combination of benefits such as market value of reclaimed materials and land as well as minimization of closure, post closure, monitoring costs. This paper presents the challenges and opportunities in implementing an integrated approach for dumpsite management and outlines strategies for incremental improvements leading to the sustainable waste management.

\section{THE APPROACH}

The phased approach involves four stages as depicted in Figure $l$ to move from open dumps to sustainable landfills $[2,3]$. The steps may vary depending on the local circumstances but all changes introduced should represent a progressive improvement over open dumping. This approach assesses alternatives and aims to provide the most benefit or least damage to the environment as a whole, at an acceptable cost in the short and long terms. "Attainability and Sustainability" should be the key to the approach.

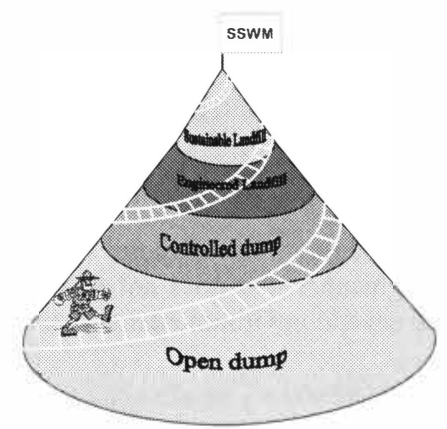

Figure 1. Phased approach to dumpsite rehabilitation in Asia. 
The first and the foremost challenge will be to decide whether the open dump should be closed and/or remediated or rehabilitated based on the environmental risks posed by it. This may involve technical investigations and Rapid Risk Assessments [4], including consultation with the interested and affected parties, especially the adjacent communities. Features of the dumps such as the depth and nature of waste, degree of compaction, variability of wastes within the site, size of the dumps as defined by the total amount of solid waste disposed of, and the real extent of the dumps, needs to be assessed. If there are a number of dumps that need to be rehabilitated and only limited resources are available, higher priority may be assigned to dumpsites with high health risk, maximum environmental impacts and public concerns and minimum rehabilitation costs. The issues of concern include operational history of the site, the rehabilitation process and after use issues and associated health risks, environmental issues and local impacts such as water and air pollution, hydro geological features, noise, dust and visual impacts, wetlands protection, and real or perceived negative neighborhood image/property value and availability of funding. When the decision is to rehabilitate or upgrade the site, steps should be taken to move from open dumping to "controlled dumping". This stage of dumpsite rehabilitation can be achieved in most middle and low-income countries in the short term without much investment. This will significantly improve the site and reduce its adverse impacts and associated nuisance. As a minimum, the following steps may be initiated to move from open dumps towards controlled dumps:

- Elimination of uncontrolled open fires

- Installation of rainwater diversion systems

- Restricting the tipping of wastes to small areas as per disposal plan

- Deposition of wastes in layers of about $50 \mathrm{~cm}$ with appropriate compaction

- Covering of newly deposited waste approximately $15 \mathrm{~cm}$ of soil or similar material on a daily basis

- Keeping the site access roads in good condition to allow vehicles to deposit wastes at designated places as quickly as possible

- Rehabilitation of scavengers

- Provision of boundary walls and access gates

- Maintenance of records of waste deliveries and tipping

- Provision of essential staff such as a landfill manager, office clerk, security, traffic controller, landfill equipment drivers, mechanic etc.

The next step will be the gradual and obvious adoption of engineering techniques such as the following:

- Control and avoidance of surface water entering the deposited wastes by installing a well designed and constructed surface drainage system

- Extraction and spreading of soil materials to cover the wastes

- Spreading and compacting wastes into smaller layers

- Collection and removal of leachate away from wastes into lagoons or similar structures

- Passive venting of landfill gas out of the wastes

- Improvements in the isolation of wastes from the surrounding geology

- Environmental monitoring and post closure care

Movement from "controlled dumping" to "engineered landfills" may be a long-term goal depending on the availability of physical and financial resources. The engineered landfill may 


\author{
Kalmar ECO-TECH '07 \\ KALMAR, SWEDEN, November 26-28, 2007
}

be operated in a sustainable way by enhancing the waste decomposition process through leachate recirculation and minimizing the long-term impacts through landfill mining. Incorporation of bio-covers is recommended for smaller landfills to mitigate methane emissions.

\title{
3 DUMPSITE CLOSURE - THE CHALLENGES
}

The dumpsites that have exhausted their volumetric capacity to hold waste are suitable candidates for closure [5]. The closure of dumpsites typically requires re-gradation of site slopes, capping of landfill with impermeable cover, placement of leachate collection and treatment systems, installation of landfill gas collection and flaring system and aesthetic landscaping of the closed dumpsite. If landfill gas volumes are significant, its utilization by way of power generation/direct supply to neighborhood community for use as fuel may be effected. As appropriate, waste materials may be moved or relocated to higher portions of the site or placed in appropriate areas to help sloping of the closed site. It is important to promote surface water drainage from landfill areas in order to prevent it from filtering into and through the garbage, thus creating ground and surface water degradation.

From an environmental point of view, the sites may still have potential for groundwater contamination. Although, one may argue that with landfill capping and leachate extraction and treatment system, contamination of groundwater will reduce over a period of time and will result in improvement in existing environmental condition (unrestricted percolation of leachate into the ground), these aspects need to be examined from the point of view of importance and use of aquifer affected by the dumpsite. Construction of commercial and residential complexes over improperly closed dumps is known to human health effect and creates damage to sensitive equipment like computers and other electronic devices [6].

A primary concern of site closure is the slope of filled portions of the site to promote surface water runoff without causing ponding or severe erosion of the final cover. Final slopes of filled portions of the landfill site should be at least $2 \%$ in grade and should not exceed $8 \%$ [7]. Terraces, drains or other measures should be used as appropriate to minimize soil erosion. The practical option for managing the large dumpsites where the average waste height is typically below $10 \mathrm{~m}$, is to plan partial closure by shifting the waste into a suitable portion of the dumpsite and closing it with a average landfill height of about $25 \mathrm{~m}$. Such a formation provides sufficient landfill volume to place the entire waste lying at the site and releases about $50 \%$ of the site area available for future waste processing and landfill operations. For shallow dumpsites (average depth of waste $5 \mathrm{~m}$ or less) common in large number of cities in Asia (population 1 to 2 million), this approach is likely to release higher area and the footprint of a tall landfill that is required to accommodate the waste strewn over the site will be even smaller.

A critical challenge in closing dumpsites is to provide a viable alternate facility or a collection system for waste disposal. The fence and gate to the site must be maintained or upgraded and the site locked to prohibit public access. The signs placed at the site should notify the public that the facility is closed, provide information on alternative disposal and specify appropriate provisions or penalties against trespassing or dumping. For a short while after site closure, problems such as disposers or vandals tearing out gates, driving through fences, dumping wastes on access roads or in ditches near the disposal facility are common. If necessary, rats 
should be exterminated to prevent their migration to populated areas. The area should be posted with adequate poison warnings.

\subsection{Building landfill on top of closed dumpsites}

Constructing a landfill on top of dump waste is not a preferred option. The typical problems related to this type of landfill are:

- As the waste is typically dumped in a haphazard manner, it would first need to be leveled. In case the height of the waste dumped is very high, its stability needs to be checked.

- As the compaction of the waste is rarely done, stability of the waste with additional load due to new landfill on top has to be accounted for.

- Movement of waste for leveling is costly and time consuming. Moreover, the activities have to be carried out in unhygienic conditions.

- Waste has to be brought to stable slopes.

- Settlement of waste over a period of time needs to be considered when designing and choosing the geotechnical material and leachate collection system.

- Release of gas has to be considered to avoid bulging.

As waste decomposes even under a capping, its volume decreases and the heap settles, leaving a dangerous vacant pocket near the top. The most attractive option of stabilizing steep side slopes of the landfill is to strengthen them externally or internally without relocating the existing waste [7]. Another simple method for stabilization of the steep side slopes is to reprofile and regrade them to gentle slope of 4 (horizontal): 1 (vertical).

When excavation works begin at large open dumps to shape the steep sides to a one-in-three slope, the opening-up of the heap releases large quantities of methane. This may cause fires and smoke. Fire-brigade efforts to douse the flames with copious water will aggravate the problem and generate more uncollected methane by introducing water deep into the airless mass which one wants to keep dry apart from generating more leachate to pollute the groundwater. This vicious cycle of methane - fire - water dousing - more methane - and leachate will persist daily unless there is a change in practices [8].

\section{DUMPSITE MINING AND RECLAMATION - THE OPPORTUNITY}

Dumpsite mining is the process of excavating the open dumps and sorting the unearthed materials for recycling, processing, or for other dispositions [9]. Typical mining process is presented in Figure 2. It employs the method of open cast mining for sorting out the mixed material from the landfill according to their size by using a screening machine. The key components are a set of conveyors and screens that sorts the solid wastes into three size fractions: oversized material, intermediate-sized waste, and dirt/humus. The quantity and characteristics of materials recovered will be a function of the landfilled wastes, the effectiveness of the type of mining technology and the efficiency with which the technology is applied. The studies carried out under the Asian Regional Research Programme on Environmental Technology funded by Swedish International Development Cooperation Agency and coordinated by Asian Institute of Technology, Thailand, [10, 11] support the feasibility of recovering about $50 \%$ of the material at the dump site as valuable fine fraction 
that can be used as daily cover for the landfill or for off-site use for growing non-edible plants. The result of toxicity characteristics leaching procedure (TCLP) revealed that this fraction is not hazardous and has potential to be reused as landfill cover material. A similar study at the Maung Pathum dumpsite in Pathumthani province, Thailand [12], showed that the stabilized waste mainly consists of soil fractions (69-75\%) with small amount of organic materials $(0.3-2.7 \%)$. However, it is possible that high concentrations of hazardous substances and heavy metals could be found in local pockets. Reclaimed soil can be used on site as daily cover on other landfill cells, thus avoiding the cost of importing cover material. Also, a market might exist for reclaimed soil for applications such as compost for non-edible crops. Energy recovery from the incineration of excavated plastic fractions with sufficient calorific value is also a feasible option.

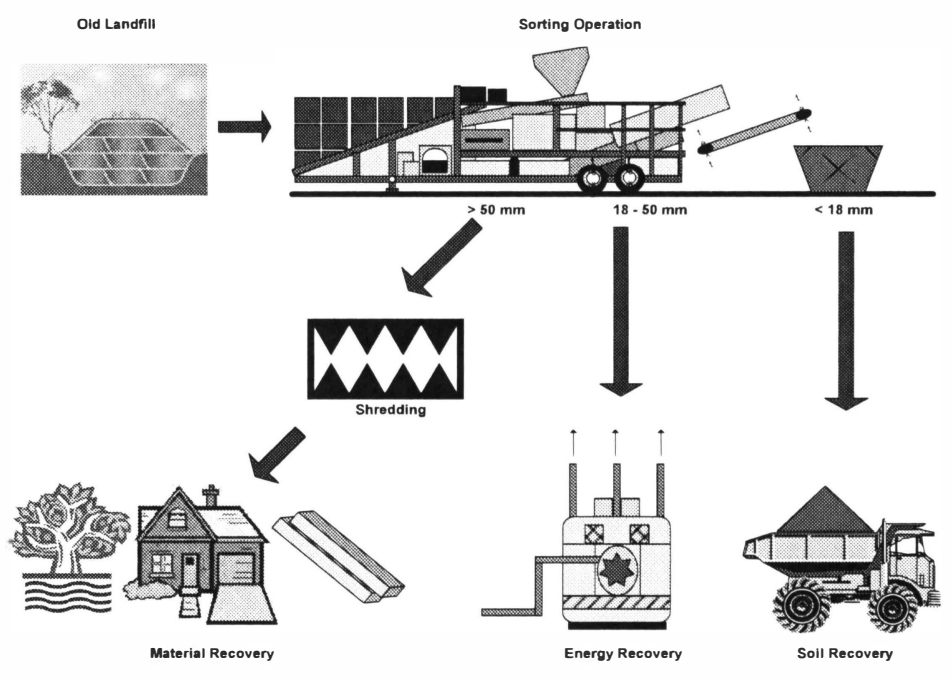

Figure 2. Schematic of a dumpsite mining process [2].

Excavated fractions that still contain high organics can be bioremediated through moisturizing by leachate recirculation and composting by open windrow approach with or without the use of biocultures [8]. This has many win-win benefits, as it can:

- Increase available post-closure area for a new scientific landfill or alternate use. The cleared area at ground level will be three times more than a small plateau at $30 \mathrm{~m}$ height above 1:3 side slopes after capping.

- Achieve near-zero emissions and leachate, instead of managing these for 15 plus years.

- Carbon credits can be sought.

- Clear the site of old waste at lower cost of conventional capping and reduce annual costs of landfill management, leachate treatment and gas monitoring. 
- Minimize the volume of old waste needing permanent burial and the requirement of scarce land for this.

- Recycle both organics and buried recyclables. Organics become converted to soilenriching compost.

The costs and benefits of landfill mining vary considerably depending on the objectives (closure, remediation, new landfill, etc.) of the project, site-specific landfill characteristics (material disposed, waste decomposition, burial practices, age and depth of fill) and local economics (value of land, cost of closure materials and monitoring). The most potential economic benefits associated with landfill reclamation are indirect. Although the economic benefits from reclamation projects are facility-specific, they may include revenue from:

- recyclable and reusable materials (e.g., ferrous metals, aluminum, plastic, and glass)

- combustible waste sold as fuel

- reclaimed soil used as cover

- materials sold as construction fill

- land value of sites reclaimed for other uses

Expenses incurred in planning of the landfill-mining project include capital and operational cost for:

- Site preparation

- Rental or purchase of reclamation, personnel safety and hauling equipment

- Construction or expansion of material handling facilities

- Labor (e.g., equipment operation and materials handling)

- Equipment fuel and maintenance

- Administrative and regulatory compliance expenses (e.g., record keeping)

- Worker training in safety procedures

- Hauling costs

In general, the economics would depend on the depth of the waste material and the ratio of wastes to soil. In most cases, the presence of hazardous materials will also affect the economic feasibility.

\subsection{Cost benefit analysis}

Analyzing the economics of dumpsite mining, it calls for investigating the current capacity and projected demand of the landfill, projected costs for landfill closure or expansion of the site, current and projected costs of future liabilities, projected markets for recycled and recovered materials and projected value of land reclaimed for other uses. Major factors influencing the cost of such projects will include the volume and topography of the dumpsite; equipment parameters; soil conditions; climate; labor rates; the regulatory approval process; excavation and screening costs; sampling and characterization; development costs; the contractor's fees; hazardous wastes disposal; and revenue from the sale of commodities such as compost and recyclables.

The quantification and monetization costs and benefits associated with the rehabilitation of a dumpsite in Chennai, India are summarized in Tables 1 and 2. The volume of the dumpsite requiring excavation and screening is estimated to be $5000000 \mathrm{~m}^{3}$ based on the dumpsite area of $100 \mathrm{ha}$ and average depth to be excavated as $5 \mathrm{~m}$. This is estimated to have a mass of 3.5 million $\mathrm{t}$ with a density of $700 \mathrm{~kg} / \mathrm{m}^{3}$. About $50 \%$ of the waste mass is considered to be soil fraction and $10 \%$ will be recyclables. The remaining $40 \%$ requires landfilling. Disposal of residuals in a landfill with a height of $15 \mathrm{~m}$ will require about 17.3 ha of land and the 
remaining land of 82.7 ha can be reclaimed and at least $90 \%$ of it will be available for future landfilling applications.

Table 1. Quantification and monetization of costs associated with rehabilitation of a dumpsite in Chennai, India.

\begin{tabular}{|c|c|c|c|c|c|}
\hline $\begin{array}{l}\text { Sl. } \\
\text { No }\end{array}$ & Item & $\begin{array}{l}\text { Quantity, } \\
\text { (wherever } \\
\text { applicable) }\end{array}$ & $\begin{array}{l}\text { Unit } \\
\text { Rate } \\
\text { (Rs.) }\end{array}$ & $\begin{array}{c}\text { Cost } \\
\text { (Rs. in } \\
\text { million) }\end{array}$ & $\begin{array}{c}\text { Cost } \\
\text { (USD in } \\
\text { million) }\end{array}$ \\
\hline 1. & $\begin{array}{l}\text { Specialist advice (engineering, } \\
\text { environmental, laboratory) involved in } \\
\text { the design and implementation of the } \\
\text { operation including site assessment, } \\
\text { base-line monitoring and community } \\
\text { consultation }\end{array}$ & $\begin{array}{l}\text { in the } \\
\text { beginning }\end{array}$ & lumpsum & 3.0 & 0.067 \\
\hline 2. & Planning and permit charges & & lumpsum & 1.0 & 0.022 \\
\hline 3. & $\begin{array}{l}\text { Site preparation, site services (power/ } \\
\text { water/drainage/site access/ internal } \\
\text { access/working platforms/ temporary } \\
\text { storage/ recycling/ materials treatment } \\
\text { areas / disposal area / site security / } \\
\text { wheel and vehicle washing/ weigh } \\
\text { bridge/haul roads }\end{array}$ & Once & lumpsum & 2.0 & 0.045 \\
\hline 4. & $\begin{array}{l}\text { Rental/Purchase of Plant and equipment } \\
\text { needs (excavation and loading plant, } \\
\text { dumper and tipper trucks, screening } \\
\text { plant and Treatment plant for leachates, } \\
\text { loading, lifting and dumping plant for } \\
\text { on-site disposal, compactors) }\end{array}$ & & & 10.0 & 0.22 \\
\hline 5. & $\begin{array}{l}\text { Excavation operation }\left(\mathrm{m}^{3}\right) \text { including } \\
\text { labour, equipment fuel and maintenance } \\
\text { Area of the dumpsite covered by the } \\
\text { waste }=100 \text { ha } \\
\text { Average depth to be excavated }=5 \mathrm{~m} \\
\text { Total volume to be excavated }= \\
5000000 \mathrm{~m}^{3}\end{array}$ & $\begin{array}{c}5000000 \\
\mathrm{~m}^{3}\end{array}$ & $100 / \mathrm{m}^{3}$ & 50.0 & 1.11 \\
\hline 6. & $\begin{array}{l}\text { Material handling and Screening } \\
\text { Operation including labour, equipment } \\
\text { fuel and maintenance }\left(5000000 \mathrm{~m}^{3} \text { at }\right. \\
\left.700 \mathrm{~kg} / \mathrm{m}^{3}=3500000 \mathrm{t}\right)\end{array}$ & $3500000 \mathrm{t}$ & $100 / \mathrm{t}$ & 35.0 & 0.78 \\
\hline 7. & $\begin{array}{l}\text { Disposal of Residuals in a landfill cell } \\
\text { including its closure (at } 40 \% \text { of } 3500000 \\
t=1400000 \mathrm{t} \text { in a landfill of } 15 \mathrm{~m} \text { height } \\
\left.\text { with a density of } 900 \mathrm{~kg} / \mathrm{m}^{3}\right)\end{array}$ & $\begin{array}{c}172846 \mathrm{~m}^{2} \\
(17.3 \mathrm{ha})\end{array}$ & $\begin{array}{c}\text { Rs. } \\
2000 / \mathrm{m}^{2}\end{array}$ & 21.0 & 0.47 \\
\hline 8. & $\begin{array}{l}\text { Project management including record } \\
\text { keeping and Environmental protection } \\
\text { measures and Monitoring of } \\
\text { arisings/recycled material/effluent and in } \\
\text { support of health and environmental } \\
\text { protection) }\end{array}$ & & lumpsum & 10.0 & 0.22 \\
\hline \multirow[t]{2}{*}{9.} & Contingency planning (at $10 \%$ ) & & & 15.0 & 0.33 \\
\hline & & & Total cost & 147.0 & 3.26 \\
\hline
\end{tabular}


Table 2. Quantification and monetization of revenue associated with rehabilitation of a dumpsite in Chennai, India.

\begin{tabular}{|c|c|c|c|c|c|}
\hline $\begin{array}{l}\text { Sl. } \\
\text { No }\end{array}$ & Item & Quantity & $\begin{array}{l}\text { Unit } \\
\text { Rate } \\
\text { (Rs.) }\end{array}$ & $\begin{array}{l}\text { Revenue } \\
\text { (Rs. in } \\
\text { million) }\end{array}$ & $\begin{array}{l}\text { Cost } \\
\text { (USD in } \\
\text { million) }\end{array}$ \\
\hline 1 & $\begin{array}{l}\text { Sale of rectaimed soil as cover soib compost } \\
\text { in place of clay (at } 50 \% \text { of } 3500000 \mathrm{t} \text { ) }\end{array}$ & $1750000 \mathrm{t}$ & $400 / \mathrm{t}$ & 70.0 & 1.56 \\
\hline 2 & $\begin{array}{l}\text { Reclaimed land for landfilling } \\
\text { at } 90 \% \text { of } \notin 100 \mathrm{e}-17.3=90 \mathrm{ha})\end{array}$ & $\begin{array}{l}7443000 \\
\mathrm{~m}^{2}\end{array}$ & $1000 / \mathrm{m}^{2}$ & 74.4 & 1.65 \\
\hline 3 & $\begin{array}{l}\text { Sale of recyctables/combustebles } \\
\text { (at } 10 \% \text { of } 3500000 t \text { ) }\end{array}$ & $350000 \mathrm{t}$ & $500 / \mathrm{t}$ & 17.5 & 0.39 \\
\hline \multicolumn{4}{|c|}{ Total revenue } & 161.2 & 3.60 \\
\hline
\end{tabular}

The project will cost Rs. 147 million as against a benefit of Rs.162 million resulting in a positive benefit to cost ratio of 1.1 and it is economical to take up the project for implementation. In practice, the environmental costs and benefits should be added to the project costs and benefits before using decision criteria like Net-Present Value, Benefit-Cost Ratio, or the Internal Rate of Return of the project. The main challenge is to estimate the environmental costs and benefits properly. Unlike project costs and benefits which are more tangible, estimating environmental costs and benefits is not so easy. As such no data are currently available to monetise the local environmental benefits that will arise out of the project from the control of smoke and air pollution due to open burning of garbage and control of odour and fly nuisance as well as ground water pollution due to leachates.

The project will also have global environmental benefits from the point of view of controlling the methane emissions that contribute to global warming. It is estimated that about $40 \%$ cost of the closure can be off-set by CDM revenues for a typical dumpsite. These estimates do not include the revenues from the sale of landfill gas or the CDM benefit that may accrue due to fuel substitution.

\section{CONCLUSIONS}

The observations made in the paper indicate that scientific rehabilitation and effective use of the dumpsites site offer several challenges and opportunities to improve the downstream components of solid waste management in Asian cities. Sound examples of scientific management of the disposal site coupled with rehabilitation of existing dumps will go a long way in alleviating the apprehensions among the neighborhoods on health, environment and value of their properties due to the proximity of waste treatment and disposal facilities. This will make it much easier to plan and site new facilities in the future. CDM benefit available in waste management sector is an important aspect that needs attention of the municipal bodies. In order to achieve the benefits, however, it will be advisable to take immediate measures to move from open dumps to controlled dumps and finally to sustainable landfills in a phased manner. The rehabilitation of a dumpsite should be preceded by a cost-benefit analysis in case of re-use of the area for other purposes or for landfilling of new waste and also for the value of potentially recoverable materials. A rapid risk assessment must be carried out before decision-making. The danger that contamination may occur during excavations, storage, 
Kalmar ECO-TECH '07

KALMAR, SWEDEN, November 26-28, 2007

transportation, recycling of material and handling of hazardous waste, mostly during intense rainfalls, must also be taken into consideration.

\section{ACKNOWLEDGEMENT}

The authors wish to thank the Swedish International Development Cooperation Agency (SIDA) for generously financing the research on "Sustainable Solid Waste Landfill Management in Asia" under the Asian Regional Research Program on Environmental Technology.

\section{REFERENCES}

[1] Visvanathan, C., Tränkler, J., Kurian, J., Chiemchaisri, C., Basnayake, B.F.A., Gongming, Z., 2004. Municipal solid waste management in Asia: Asian Regional Research Program on Environmental Technology. AIT Publication, Thailand. ISBN: 974-417-258- Available online: http://www.swlf.ait.ac.th/.

[2] Kurian Joseph, Nagendran, R., Palanivelu, K., Thanasekaran, K., Visvanathan, C., 2004. Dumpsite rehabilitation and landfill mining, Centre for Environmental Studies, Anna University, Chennai-600 025, India

[3] Rushbrook, P., 2001. Guidance on minimum approaches for improvements to existing municipal waste dumpsites, WHO Regional Office for Europe, Copenhagen.

[4] Kurian Joseph, Esakku, S., Nagendran, R., Visvanathan, C., 2005. A decision making tool for dumpsite rehabilitation in developing countries, Proceedings Sardinia 2005, $\mathrm{X}$ International Waste Management and Landfill Symposium, Italy.

[5] Joshi, V., Nachiyappan, N.C., 2007. Management of old MSW dumps - challenges and opportunities, Procs. International Conference on Sustainable Solid waste Management, Anna University, Chennai, India, pp 334-340.

[6] Sahu, A.K., 2007. Present scenario of municipal solid waste dumping grounds in India, Procs. International Conference on Sustainable Solid waste Management, Anna University, Chennai, India, pp 327-333.

[7] Datta, M., Vittal Veera, P.R.V., 2007. Stability of cover systems for landfills and old waste dumps, Procs. International Conference on Sustainable Solid waste Management, Anna University, Chennai, India, pp 312-319

[8] Patel, A.H., 2007. Bioremediation of old landfills, Proceedings International Conference on Sustainable Solid waste Management, Anna University, Chennai, India, pp 304-311.

[9] Hogland, W., Marques, M., Nimmermark, S., 2004. Landfill mining and waste characterization: a strategy for remediation of contaminated areas, J Mater Cycles Waste Manag, 6, 119-124.

[10] Kurian Joseph, Esakku, S., Palanivelu, K., Selvam, A., 2003. Studies on landfill mining at solid waste dumpsites in India, In: Procs. Sardinia 2003, Ninth International Waste Management and Landfill Symposium, 6-10 October, Cagliari, Italy.

[11] Esakku, S., Palanivelu, K., Kurian Joseph, 2003. Assessment of heavy metals in a municipal solid waste dumpsite. In: Proceedings of the Workshop on Sustainable Landfill Management, Chennai, India, 3-5 December 2003, pp 139-145.

[12] Rattanaoudum, R., 2004. Rehabilitation and material recovery assessment in Maung Pathum Dumpsite, Thailand, Master Thesis, Asian Institute of Technology, Bangkok. 